\title{
HUBUNGAN KEMATANGAN EMOSI TERHADAP PERILAKU AGRESIF SISWA MADRASAH ALIYAH DAN SEKOLAH MENENGAH KEJURUAN
}

\author{
Raja Fitrina Lestari ${ }^{1}$, Agus Susanto ${ }^{2}$ \\ ${ }_{1,2}$ PSIK STIKes Hang Tuah Pekanbaru \\ J1. Mustafa Sari No.5 Tangkerang Selatan Pekanbaru \\ Hp. 081278946408 \\ Email : fitrina_raja@yahoo.co.id
}

\begin{abstract}
Abstrak
Perilaku agresif adalah perbuatan yang diniati untuk menyakiti orang lain, baik secara fisik maupun psikologis. Salah satu pemicu dari perilaku agresif adalah ketika seseorang mengalami satu kondisi emosi tertentu, yang sering terlihat adalah emosi marah. Penelitian ini bertujuan untuk mengetahui hubungan kematangan emosi terhadap perilaku agresif siswa Madrasah Aliyah (MA) dan Sekolah Menengah Kejuruan (SMK) di Pesantren Teknologi Riau Pekanbaru. Jenis penelitian ini adalah penelitian kuantitatif dengan menggunakan desain penelitian cross sectional. Sampel dalam penelitian ini adalah 144 orang siswa Madrasah Aliyah (MA) dan Sekolah Menengah Kejuruan (SMK) di Pesantren Teknologi Riau Pekanbaru yang diambil secara total sampling. Analisa yang digunakan adalah analisa univariat dengan menggunakan distribusi frekuensi, analisis bivariat dengan uji statistik Chi-square. Hasil uji analisis bivariat didapatkan $p$ value 0,000 ( $\mathrm{p}<0,05)$, maka dapat disimpulkan ada hubungan antara kematangan emosi dengan perilaku agresif siswa Madrasah Aliyah (MA) dan Sekolah Menengah Kejuruan (SMK) di Pesantren Teknologi Riau Pekanbaru. Diharapkan Pesantren Teknologi Riau Pekanbaru dapat meningkatkan bimbingan kepada para siswa tentang pentingnya pengendalian emosi dan akibatnya jika emosi tidak dapat dikendalikan.
\end{abstract}

Kata Kunci : Kematangan Emosi, Prilaku Agresif

\begin{abstract}
Aggressive behavior is intentional act to hurt others, either physically or psychologically. One of the triggers of aggressive behavior is when a person experiences a certain emotional state, which is often seen is the emotion of anger. This study aims to determine the relationship of emotional maturity toward aggressive behavior of students Madrasah Aliyah (MA) and vocational schools) in Pesantren Technology Riau Pekanbaru. This research is a quantitative study using cross sectional study design. The sample in this study was 144 students Madrasah Aliyah (MA) and vocational schools in Pesantren Technology Riau Pekanbaru taken by total sampling. The analysis used is a univariate analysis using frequency distribution, bivariate analysis using Chi-square test statistic. Bivariate analysis of test results obtained p value of $0.000(p<0.05)$, it can be concluded that correlation between emotional maturity with aggressive behavior of students Madrasah Aliyah (MA) and vocational schools in Pesantren Technology Riau Pekanbaru. Riau Pekanbaru expected Pesantren technology can improve guidance to its students about the importance of emotional control and emotional consequences if not controlled.
\end{abstract}

Keywords : Aggressive Behavior, Emotional Maturity

\section{PENDAHULUAN}

Remaja adalah generasi yang paling berpengaruh dalam mewujudkan cita-cita suatu bangsa dan generasi penerus yang diharapkan bisa merubah keadaan bangsanya menjadi bangsa yang lebih baik. Santrock (2007) mendefinisikan remaja sebagai masa perkembangan transisi antara anak dan masa dewasa yang mencakup perubahan biologis, kognitif, dan sosial-emosional.

Keadaan remaja di Indonesia saat ini sangat memprihatinkan, dimana saat ini remaja cenderung lebih bebas dan jarang memperhatikan nilai moral yang terkandung dalam setiap perbuatan yang mereka lakukan. Remaja mempunyai sifat yang cenderung lebih 
Raja Fitrina Lestari ${ }^{1}$, Agus Susanto ${ }^{2}$,Hubungan Kematangan Emosi terhadap Perilaku Agresif Siswa Madrasah Aliyah dan Sekolah Menengah Kejuruan

agresif, emosi tidak stabil, dan tidak bias menahan dorongan nafsu. Hal tersebut engakibatkan remaja yang tidak bisa menyesuaikan atau beradaptasi dengan lingkungan yang selalu berubah-ubah akan melakukan perilaku yang maladaptif, contohnya perilaku agresif yang dapat merugikan orang lain dan juga diri sendiri (Santrock, 2007).

Nashori (2008) mengutip dari pernyataan Brigham dalam bukunya bahwa perilaku agresif adalah perbuatan yang diniati untuk menyakiti orang lain, baik secara fisik maupun psikologis. Sementara itu, beberapa tokoh seperti Freud dan Lorenz menyatakan bahwa agresif dan kekerasan adalah salah satu wujud kehendak untuk mati dan naluri untuk mempertahankan hidup. Karena bersifat naluriah, maka setiap saat perilaku tersebut dapat muncul, terlebih dalam situasi hidup yang mengancam eksistensi kehidupan seseorang. Myers (2012) menyatakan bahwa konsep agresif adalah sebagai perilaku fisik atau verbal yang dimaksudkan untuk menyebabkan kerusakan. Bentuk klasifikasi tersebut masing-masing akan saling berinteraksi sehingga menimbulkan beberapa perilaku agresif yang dapat berdampak bagi fisik maupun psikologis orang lain (Nashori, 2008).

Berbagai bentuk kekerasan di Indonesia yang merupakan implementasi dari perilaku agresif sering kita lihat tidak hanya melalui film di televisi, melainkan dalam pemberitaan baik melalui media elektronik maupun media massa bahkan hingga menyebabkan kematian. Pada tanggal 20 Desember 2011 sekitar pukul 12.20 WIB terdapat 82 pelajar tewas akibat kasus tawuran, sedangkan 105 orang lainnya ada yang mengalami luka berat dan ringan (Amelia, 2011).

Berdasarkan Data pengaduan Komisi Perlindungan Anak Indonesia (KPAI) Tahun 2015, menunjukkan bahwa anak korban kekerasan sebanyak 127 siswa, sementara anak menjadi pelaku kekerasan di sekolah 64 siswa. Anak korban tawuran 71 siswa, sementara anak menjadi pelaku tawuran 88 siswa. Plan International dan International Center for Research on Women (ICRW) melaporkan bahwa terdapat $84 \%$ anak di Indonesia mengalami kekerasan di sekolah. Angka tersebut lebih tinggi dari tren di kawasan Asia yakni $70 \%$. Selain itu, data dari Badan PBB untuk Anak (Unicef) menyebutkan, 1 dari 3 anak perempuan dan 1 dari 4 anak laki-laki di Indonesia mengalami kekerasan (Setyawan, 2016).

Kota Pekanbaru tahun 2012-2013 terdapat kasus kekerasan yang dilakukan remaja yang bergabung dalam satu kelompok geng motor. Tahun 2012 tercatat sebanyak 25 kasus pidana yang dilakukan geng motor; Januari 
Mei tahun 2013 tercatat delapan kasus. Tindakan kriminal yang mereka lakukan antara lain pencurian dengan kekerasan, pengrusakan, penganiayaan, hinga pemerkosan terhadap korban (Anggoro, 2013).

Pemicu yang umum dari perilaku agresif tersebut adalah ketika seseorang mengalami satu kondisi emosi tertentu, yang sering terlihat adalah emosi marah. Perasan marah berlanjut pada keinginan untuk melampiaskanya dalam satu bentuk tertentu dan pada objek tertentu. Sedangkan faktor yang menyebabkan terjadinya perilaku agresif pada remaja yaitu faktor internal (dari dalam) maupun faktor eksternal (dari luar). Faktor internal meliputi: frustasi, ganguan pengamatan dan tanggapan remaja, ganguan berfikir dan intelegency remaja, serta ganguan perasan/emosional remaja sedangkan faktor eksternal meliputi faktor keluarga, faktor sekolah dan faktor lingkungan (Kartono, 2011).

Pesantren Teknologi Riau adalah salah satu pondok pesantren yang berada di kota Pekanbaru yang menaungi tiga sekolah, yaitu Madrasah Tsanawiyah (MTs), Madrasah Aliyah (MA) dan Sekolah Menengah Kejuruan (SMK). Pesantren Teknologi Riau merupakan sekolah yang berbasis keagamaan yang banyak memberikan nilai-nilai positif bagi siswanya. Dengan kondisi ini seyogyanya perilaku agresif itu tidak akan terjadi atau tidak dilakukan oleh santri Pondok Pesantren Teknologi Riau. Namun ternyata hal tersebut tidak sepenuhnya terealisasi di Pondok Pesantren Teknologi Riau. Hal ini dikarenakan berbagai tindak kekerasan yang merupakan salah satu bentuk perilaku agresif juga terjadi di lingkungan Pesantren Teknologi Riau. Data tersebut peneliti peroleh berdasarkan wawancara awal pada 5 Januari 2015 dengan guru BK Pesantren Teknologi Riau.

Berdasarkan hasil wawancara kepada 25 santri baik putra maupun putri, ditemukan beberapa fakta antara lain 68,6\% (17 orang santri) yang didominasi oleh santri putra sebanyak sebelas orang $(44,4 \%)$ dan enam orang santri putri $(24,2 \%)$, mengakui pernah mengalami tindak kekerasan fisik yang dilakukan oleh kakak tingkat (senior) mereka seperti dipukul dan ditampar serta kekerasan verbal seperti dihina dan disindir. Dari tindak kekerasan baik fisik maupun psikis yang mereka terima itu menyebabkan mereka merasa tidak nyaman.

Perasaan ketidaknyamanan para santri juga sering dirasakan ketika para santri junior menerima hukuman dari senior yang sebenarnya mereka merupakan perpanjangan tangan dari pengasuh asrama yang bertugas mengawasi adik tingkatnya. Namun, penyelewengan kewenangan sering terjadi disini yang menyebabkan mereka sering bertindak sekehendak hati mereka, yang imbasnya dirasakan oleh santri junior, salah satu contohnya pernah terjadi pada AS (nama samaran) yang mendapatkan hukuman fisik yaitu berupa penamparan yang dilakukan oleh 
Raja Fitrina Lestari ${ }^{1}$, Agus Susanto ${ }^{2}$,Hubungan Kematangan Emosi terhadap Perilaku Agresif Siswa Madrasah Aliyah dan Sekolah Menengah Kejuruan

senior yang merupakan perpanjangan tangan dari pengasuh asrama. Padahal berdasarkan aturan yang berlaku di asrama untuk kasus yang dilakukan oleh AS yaitu pencurian, hukumannya adalah teguran oleh pengasuh asrama dan untuk selanjutnya diberlakukan hukuman yang mendidik seperti membersihkan pekarangan asrama, bukan tamparan (wawancara dengan guru BK dan santri).

Beberapa permasalahan yang terjadi di atas menjadi perhatian yang serius, baik bagi pengasuh asrama, guru (wali kelas) maupun kepala sekolah sendiri. Keadaan demikian seharusnya tidak terjadi di lingkungan pesantren yang sebagian besar didominasi oleh lingkungan yang agamis, namun faktanya terjadi peningkatan perilaku agresif santri setiap tahunnya. Diketahui bahwa angka kejadian tertinggi (perilaku agresif terbanyak) terjadi sepanjang bulan Januari-Oktober 2014, yaitu tujuh pelanggaran yang tergolong kedalam perilaku agresif fisik dan agresif verbal.

Berdasarkan data awal, berbagai bentuk perilaku agresif yang terdapat di lapangan dan beberapa penjelasan dari penelitian terdahulu yang terkait dengan penelitian yang akan peneliti lakukan, maka hal tersebut menarik minat peneliti untuk meneliti mengenai hubungan kematangan emosi terhadap perilaku agresif siswa Madrasah Aliyah (MA) dan Sekolah Menengah Kejuruan (SMK) di Pesantren Teknologi Riau Pekanbaru.

\section{METODOLOGI}

Penelitian ini penelitian kuantitatif dengan pendekatan cross sectional. Responden penelitian sebanyak 144 siswa Madrasah Aliyah (MA) dan Sekolah Menengah Kejuruan (SMK) Pesantren Teknologi Riau Pekanbaru yang ada pada saat penelitian berlangsung diambil secara total sampling. Pengambilan data pada 11 Agustus 2015 s/d 23 Januari 2016 dengan menggunakan kuesioner. Analisa data menggunakan Chi-square untuk mengetahui hubungan kematangan emosi terhadap perilaku agresif siswa.

\section{HASIL}

\section{Analisis Univariat}

Tabel 1

Karakteristik responden berdasarkan jenis kelamin dan umur

\begin{tabular}{lll}
\hline $\begin{array}{l}\text { Karakteristik } \\
\text { Responden }\end{array}$ & $\begin{array}{l}\text { Frekuensi } \\
\text { (f) }\end{array}$ & $\begin{array}{l}\text { Persentase } \\
(\%)\end{array}$ \\
\hline $\begin{array}{l}\text { Jenis Kelamin } \\
\text { L (Laki-laki) }\end{array}$ & 54 & 37,5 \\
P (Perempuan) & 90 & 62,5 \\
\hline Umur & & \\
16 Tahun & 51 & 35,4 \\
17 Tahun & 53 & 36,8 \\
18 Tahun & 40 & 27,8 \\
\hline
\end{tabular}

Berdasarkan tabel 1 didapatkan bahwa sebagian besar responden berjenis kelamin perempuan yaitu 90 orang $(62,5 \%)$ dan berumur 17 tahun yaitu 53 orang $(36,8 \%)$. 
Tabel 2

Gambaran kematangan emosi responden

\begin{tabular}{lll}
\hline $\begin{array}{l}\text { Kematangan } \\
\text { Emosi }\end{array}$ & $\begin{array}{l}\text { Frekuensi } \\
(\mathbf{f})\end{array}$ & $\begin{array}{l}\text { Persentase } \\
(\boldsymbol{\%})\end{array}$ \\
\hline Buruk & 73 & 50,7 \\
Baik & 71 & 49,3 \\
\hline Total & $\mathbf{1 4 4}$ & $\mathbf{1 0 0}$ \\
\hline
\end{tabular}

Berdasarkan tabel 2 diketahui bahwa sebagian besar responden memiliki kematangan emosi pada kategori buruk yaitu 73 orang $(50,7 \%)$.
Tabel 3

Gambaran perilaku agresif responden

\begin{tabular}{lll}
\hline Prilaku Agresif & $\begin{array}{l}\text { Frekuensi } \\
\text { (f) }\end{array}$ & $\begin{array}{l}\text { Persentase } \\
(\mathbf{\%})\end{array}$ \\
\hline Tinggi & 93 & 64,6 \\
Rendah & 51 & 35,4 \\
\hline Total & $\mathbf{1 4 4}$ & $\mathbf{1 0 0}$
\end{tabular}

Berdasarkan tabel 3 diketahui bahwa mayoritas responden memiliki perilaku agresif pada kategori tinggi yaitu 93 orang $(64,6 \%)$.

\section{Analisis Bivariat}

Tabel 4

Hubungan kematangan emosi dengan perilaku agresif responden

\begin{tabular}{|c|c|c|c|c|c|c|c|c|}
\hline \multirow{3}{*}{ Kema- tangan Emosi } & \multicolumn{6}{|c|}{ Perilaku Agresif } & \multirow{3}{*}{ OR 95\% CI } & \multirow{3}{*}{$p_{\text {value }}$} \\
\hline & \multicolumn{2}{|c|}{ Rendah } & \multicolumn{2}{|c|}{ Tinggi } & \multicolumn{2}{|c|}{ Total } & & \\
\hline & $\mathrm{n}$ & $\%$ & $\mathbf{n}$ & $\%$ & n & $\%$ & & \\
\hline Baik & 38 & 52,1 & 35 & 47,9 & 73 & 100 & & \\
\hline Buruk & 13 & 18,3 & 58 & 81,7 & 71 & 100 & $\begin{array}{c}4,844 \\
273-10323)\end{array}$ & 0,000 \\
\hline Total & 51 & 35,4 & 93 & $\overline{64,6}$ & 144 & 100 & & \\
\hline
\end{tabular}

Berdasarkan tabel 4 diketahui dari 73 responden yang mempunyai kematangan emosi baik $38(52,1 \%)$ responden memiliki prilaku agresif rendah dan dari 71 responden yang mempunyai kematangan emosi buruk 13 $(18,3 \%)$ responden memiliki perilaku agresif rendah. Hasil uji chi-square diperoleh $p_{\text {value }}=$ $0,000(p<0,05)$, maka dapat disimpulkan ada hubungan yang bermakna antara kematangan emosi dengan perilaku agresif siswa Madrasah Aliyah (MA) dan Sekolah Menengah Kejuruan (SMK) di Pesantren Teknologi Riau Pekanbaru. Perhitungan risk estimate didapatkan OR 4,844 (OR>1) dengan 95\% CI =2,273-10,323, hal ini menunjukkan bahwa responden yang memiliki kematangan emosi pada kategori baik mempunyai kecenderungan 4,844 memilih perilaku agresif pada kategori rendah dibandingkan dengan responden yang memiliki kematangan emosi pada kategori rendah.

\section{PEMBAHASAN}

Berdasarkan hasil penelitian di Pesantren Teknologi Riau Pekanbaru didapatkan bahwa mayoritas responden memiliki kematangan emosi pada kategori buruk yaitu 73 orang $(50,7 \%)$ dan memiliki perilaku agresif pada kategori tinggi yaitu 93 orang (64,6\%). Hasil uji statistik menunjukkan bahwa ada hubungan yang bermakna antara kematangan emosi dengan prilaku agresif siswa Madrasah Aliyah 
Raja Fitrina Lestari ${ }^{1}$, Agus Susanto ${ }^{2}$,Hubungan Kematangan Emosi terhadap Perilaku Agresif Siswa Madrasah Aliyah dan Sekolah Menengah Kejuruan

(MA) dan Sekolah Menengah Kejuruan (SMK) di Pesantren Teknologi Riau Pekanbaru dengan $p_{\text {value }}=0,000(p<0,05)$.

Hasil penelitian ini sejalan dengan teori yang dikemukakan oleh Rahayu (2011) bahwa perilaku agresif dipengaruhi oleh faktor internal dan faktor eksternal. Faktor internal yakni faktor yang ada dalam diri seseorang yang berupa kematangan emosi yang kurang baik. Seseorang yang telah matang emosinya berarti dia mampu dalam mengendalikan luapan emosi dan nafsu-Nya, sehingga seseorang tersebut dapat mengelolanya dengan baik. Sedangkan faktor eksternal yakni faktor yang berada dilingkungan sekitar yang berupa stimulus yang kurang baik yang diterima dari lingkungannya, salah satunya dari keluarga maupun teman sebayanya.

Emosi marah yang bersifat negatif dan meledak-ledak disertai dengan faktor eksternal seperti frustrasi dan provokasi, menyebabkan terjadinya proses penyaluran energi negatif berupa dorongan agresi yang akan mempengaruhi perilaku individu. Individu dengan tingkat kematangan emosional tinggi mampu meredam dorongan agresi dan mengendalikan emosinya, pandai membaca perasaan orang lain, serta dapat memelihara hubungan baik dengan lingkungannya, sehingga apabila individu memiliki kematangan emosi yang baik, maka individu tersebut mampu mengendalikan perilaku agresinya (Aprius \& Fajar, 2011).
Penelitian ini sejalan dengan penelitian Fitriana (2009) tentang hubungan antara kematangan emosi dengan perilaku agresi pada siswa di SMK Muhammadiyah 1 Malang, mendapatkan bahwa ada hubungan antara kematangan emosi dengan perilaku agresi pada siswa di SMK Muhammadiyah 1 Malang. Penelitian Popeuna (2014) yang meneliti tentang hubungan kematangan emosi dengan perilaku agresif pada remaja di SMP Negeri 7 Banda Aceh, juga mendapatkan bahwa ada hubungan kematangan emosi dengan perilaku agresif pada remaja di SMP Negeri 7 Banda Aceh.

Penelitian ini juga sejalan dengan penelitian Putri (2010) tentang hubungan antara kematangan emosi dengan agresivitas remaja akhir laki-laki, yang mendapatkan bahwa terdapat hubungan yang signifikan antara kematangan emosi dengan agresivitas remaja akhir laki-laki.

Berdasarkan hasil penelitian dan teori di atas, maka dapat disimpulkan bahwa ada hubungan kematangan emosi dengan perilaku agresif siswa Madrasah Aliyah (MA) dan Sekolah Menengah Kejuruan (SMK) di Pesantren Teknologi Riau Pekanbaru. Dengan demikian dapat diartikan bahwa siswa yang mempunyai kematangan emosi yang tinggi mampu mengelola emosinya seperti mandiri, mempunyai kemampuan untuk menerima realita, dapat beradaptasi dengan baik, kesiapan merespon emosi orang lain dengan tepat, kemampuan untuk seimbang dengan 
kehidupan sosialnya, kemampuan berempati dengan pengendalian amarah yang baik.

\section{SIMPULAN}

Berdasarkan penelitian yang dilakukan pada siswa Madrasah Aliyah (MA) dan Sekolah Menengah Kejuruan (SMK) di Pesantren Teknologi Riau Pekanbaru tentang hubungan yang bermakna antara kematangan emosi dengan perilaku agresif remaja didapatkan yaitu 90 orang $(62,5 \%)$ dan berumur 17 tahun yaitu 53 orang (36,8\%), maka disimpulkan: Ada hubungan yang bermakna antara kematangan emosi dengan perilaku agresif siswa Madrasah Aliyah (MA) dan Sekolah Menengah Kejuruan (SMK) di Pesantren Teknologi Riau Pekanbaru.

\section{SARAN}

1. Diharapkan responden dapat mengontrol emosinya, tidak mudah terhasut serta menghindari konflik yang dapat merugikan diri sendiri dan orang lain.

2. Diharapkan Pesantren Teknologi Riau Pekanbaru dapat meningkatkan bimbingan kepada santrinya tentang pentingnya pengendalian emosi dan akibatnya jika emosi tidak dapat dikendalikan.

3. Hasil penelitian ini di harapkan dapat menjadi bahan informasi atau referensi dalam melakukan penelitian lain yang berhubungan dengan kematangan emosi dan perilaku agresif serta menambahkan variabel lain seperti pola asuh orang tua, lingkungan sosial, pergaulan siswa yang mungkin berhubungan dengan perilaku agresif siswa.

\section{DAFTAR PUSTAKA}

Amelia, E Mei. (2011). Tawuran pelajar memakan banyak korban. Diperoleh dari http://news.detik.com

Anggoro. (2013). Polisi Pekanbaru buru geng motor hingga ke sekolah. Antara news. Diperoleh dari http:/www.antaranews. com

Aprius, M. G \& Fajar, K. (2011). Perilaku agresi pada mahasiswa ditinjau dari kematangan emosi. (Vol 1, No. 2, hlm 86-92), Jurnal Psikologi Pitutur.

Fitriana, N. J. (2009). Hubungan antara kematangane emosi dengan perilaku agresi pada siswa Di SMK Muhammadiyah 1 Malang. [online]. Diperoleh dari http://Karya-Ilmiah. um.ac.id/. Diakses pada 15 Januari 2015.

Kartono, K. (2011). Psikologi anak. Bandung: Mandar Maj.

Myers, D. (2012). Psikologi sosial Jilid 2. Jakarta : Salemba Humanika.

Nashori, Fuad. (2008). Psikologi sosial islami. Bandung : Refika Aditama.

Popeuna, J. (2014). Hubungan kematangan emosi dengan perilaku agresif pada remaja Di SMP Negeri 7 Banda Aceh. Fakultas Keperawatan Universitas Syiah Kuala Banda Aceh. [online]. Diperoleh dari http://etd.unsyiah.ac.id/. Diakses pada 22 Maret 2015.

Putri. F. A. (2010). Hubungan kematangan emosi dengan agresivitas remaja akhir laki-laki. Jakarta: Fakultas Psikologi Universitas Islam Negeri Syarif Hidayatullah Jakarta. [online]. Diperoleh dari http://repository.uinjkt.ac.id/. Diakses 9 Desember 2015.

Santrock, J.W. (2007). Remaja. Jakarta: Erlangga.

. (2012). Perkembangan masa

hidup. jilid 1. Ed 13 . Jakarta: Erlangga. 
Raja Fitrina Lestari ${ }^{1}$, Agus Susanto ${ }^{2}$,Hubungan Kematangan Emosi terhadap Perilaku Agresif Siswa Madrasah Aliyah dan Sekolah Menengah Kejuruan

Sarwono, S. W. (1999). Psikologi sosial: individu dan teori-teori psikologi sosial. Jakarta: Balai Pustaka.

\section{(2013). Psikologi Remaja.} Jakarta: Raja Grafindo Persada

Setyawan, D. (2016). Quo vadis perlindungan anak di sekolah: antara norma dan realita. Diperoleh dari http://www.kpai. go.id/berita/kpai-quo-vadis-perlindungan -anak-di-sekolah-antara-norma-danrealita/. Diakses pada 22 Maret 2015 